\title{
The Seroprevalence of Toxoplasma gondii in Wild Boars from Three Voivodeships in Poland, MAT Analyses
}

\author{
Aleksandra Kornacka ${ }^{1}$ - Bożena Moskwa ${ }^{1} \cdot$ Anna Werner ${ }^{2} \cdot$ Piotr Nowosad $^{2} \cdot$ Wiesława Jankowska ${ }^{2}$. \\ Aleksandra Cybulska ${ }^{1} \cdot$ Anna C. Majewska $^{3}$
}

Received: 29 October 2019 / Accepted: 14 February 2020 / Published online: 2 March 2020

(c) The Author(s) 2020

\begin{abstract}
Purpose The European wild boar (Sus scrofa) is a popular game animal species. Its meat, however, can represent a reservoir of dangerous foodborne diseases and can play an important role in the transmission of many pathogens, including Toxoplasma gondii, in humans and animals worldwide. The aim of the present study was to determine the presence of antibodies to $T$. gondii in the serum of hunted wild boars in Poland.

Methods Using the commercial direct agglutination test, 398 serum samples collected during the hunting season 2009/2010 were tested for the presence of $T$. gondii antibodies, and the titre of 40 was considered indicative of $T$. gondii infection in analysed samples.

Results It was found that nationwide, 37.7\% were seropositive to $T$. gondii, although seroprevalence varied from 11.6 to $50 \%$ depending on the Voivodeship. Significant differences were observed between the Great Poland and Lubusz Voivodeships and between Great Poland and Warmian-Masurian.

Conclusion Serological test indicated widespread exposure to $T$. gondii by wild boar; therefore, consumption of raw or undercooked game meat of infected animals can carry a significant risk of $T$. gondii infection.
\end{abstract}

Keywords Toxoplasma gondii $\cdot$ Wild boars $\cdot$ Modified agglutination test $\cdot$ Antibodies

\section{Introduction}

The wild boar (Sus scrofa) is one of the most widely distributed large mammals across the territory of Poland and Europe [24]. The species engages in destructive behaviour and causes damage to agricultural fields, for this $S$. scrofa is considered one of the hundred most harmful invasive species [25].

Because of their behavioural characteristics and omnivorous eating habits (consuming mainly plant matter but also live and dead animals), the wild boar is a potential carrier

Aleksandra Kornacka

kornacka.aleksandra@twarda.pan.pl

1 Witold Stefański Institute of Parasitology, Polish Academy of Sciences, Twarda 51/55, 00-818 Warsaw, Poland

2 Department of Biology and Medical Parasitology, Faculty of Medicine I, Poznan University of Medical Sciences, Fredry 10, 61-701 Poznan, Poland

3 Poznan University of Medical Sciences, Fredry 10, 61-701 Poznan, Poland of viral, bacterial, and parasitic diseases such as porcine circovirus, tuberculosis, trichinellosis and toxoplasmosis that can affect livestock, wildlife and humans [28].

In accordance with FAO, $T$. gondii it is the fourth most important foodborne parasite (the first among the protozoa) worldwide [12]. The parasite infects most warm-blooded animals including humans. Wild and domestic felids are the definitive hosts (excrete the oocysts in their faeces), while many mammals and avian species are intermediate hosts [10]. After primary infection, a single cat may shed more than 100 million oocysts into the environment [37]. Under environmental conditions with sufficient aeration, humidity, and warm temperature, oocysts may sporulate and become infective in less than 1 day. Human toxoplasmosis is usually acquired by three principal routes: (1) ingestion of oocysts in material contaminated by faeces of infected, shedding felines, (2) ingestion of $T$. gondii cysts in raw or undercooked meat of infected animals, or (3) transplacental transmission of the parasite tachyzoites from a parasitemic host to its foetus. Although $T$. gondii infection is usually asymptomatic in humans, it can cause considerable morbidity and mortality 
especially in immunocompromised individuals. Pregnant woman can congenitally infect the foetus, tachyzoites of $T$. gondii are capable to pass through placenta, and the damage caused by this parasite to the unborn child is often more severe the earlier in pregnancy the transmission occurs [19].

Over the last decade, food habits have been changing constantly, and as wildlife meat is widely regarded as being healthier, consumption of game meat has become more popular. Meat from infected animals is considered the most important source of T. gondii human infections [17]. Also, the European Food Safety Authority (EFSA) reports that more than $50 \%$ of all human toxoplasmosis cases are foodborne $[11,35]$.

In addition, the disease burden of human toxoplasmosis on healthcare systems in Western countries is ranked second among the most common foodborne pathogens for causing death [11]. However, in many countries, no data are given regarding the prevalence of $T$. gondii infection in human or animal populations, which suggests that the disease is still widely underestimated and scarcely investigated [38].

Since tissue cysts are not visible on postmortem inspection, meat of infected animals represents a source of infection for man [34]. The risk of infection is further increased by the consumption of the hunted wild boar by hunters and their families, or the use of meat of infected animals in products intended for the local market. Where hunters leave animal carcasses or leftovers of deer, boars or foxes out in the field, there is a chance that wild boars scavenge on them, leading to further chances of infection with Toxoplasma.

The aim of the present study was to determine the occurrence of antibodies to $T$. gondii in wild boars from three Voivodeships in Poland by modified agglutination test (MAT).

\section{Materials and Methods}

Blood samples were collected from 398 wild boars in 2009-2010 during hunting season in Poland, supervised by the Polish Hunting Association. The study was performed in three Voivodeships: Warmian-Masurian $(n=48)$, Greater Poland ( $n=69)$, Lubusz $(n=281)$ (Fig. 1). Blood was collected in sterile tubes directly from the thoracic cavity upon evisceration. The sera were separated and kept at $-20{ }^{\circ} \mathrm{C}$ until analysis. No data about sex and age was available.

\section{Area of the Study}

Warmian-Masurian Voivodeship is located in north-eastern Poland, the area of $24,192 \mathrm{~km}^{2}$ consists mainly of forests,
Fig. 1 Map showing the sampling areas and the seroprevalence of Toxoplasma gondii

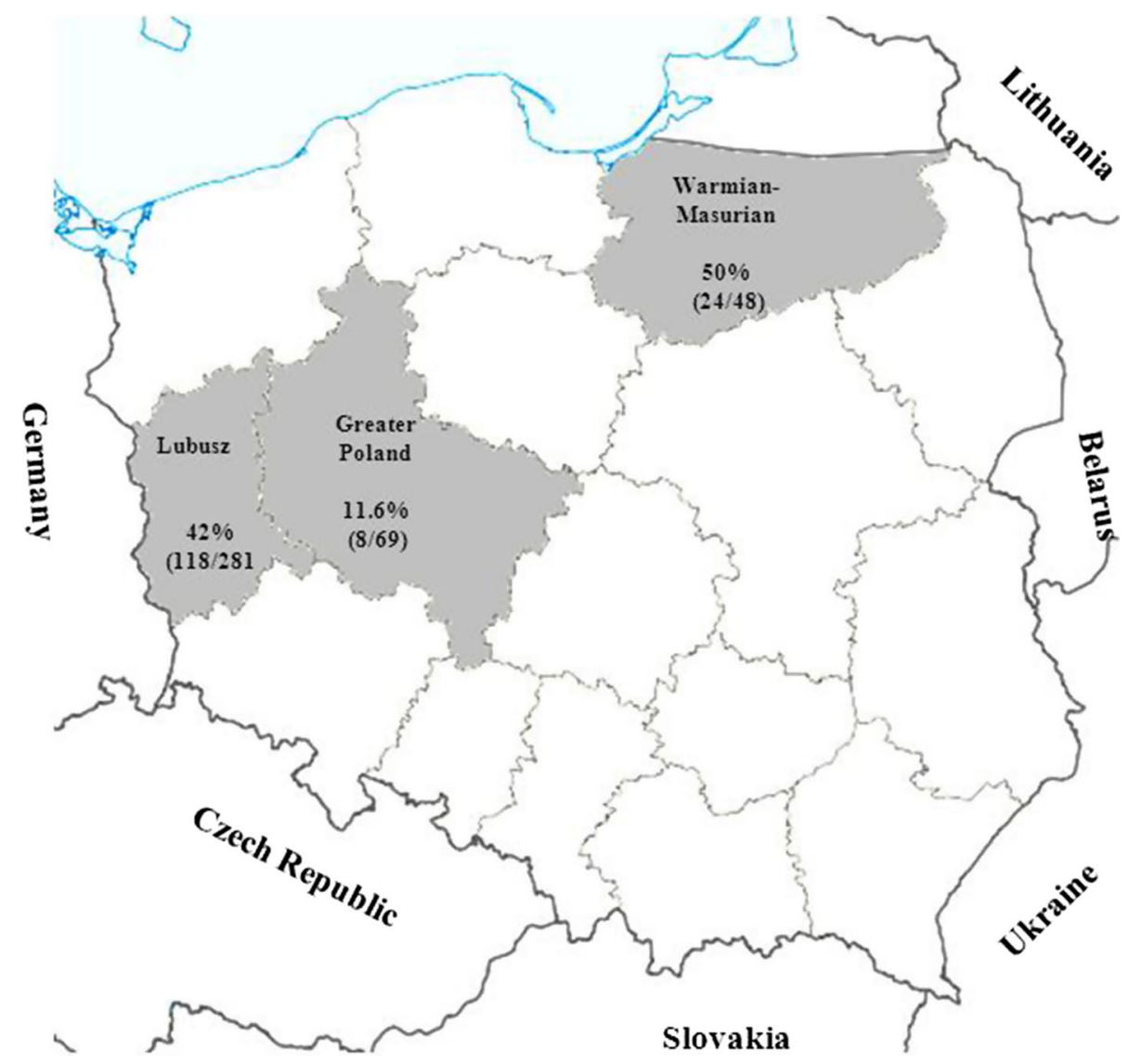


lakes and agricultural fields and farms. According to Polish Institute of Meteorology and Water Management-National Research Institute reports, the overall precipitation is $600.3-729.0 \mathrm{~mm}$, average annual temperature is $6.8-6.2^{\circ} \mathrm{C}$ with humidity about $83.0-84.3 \%$.

Lubusz Voivodeship is the smallest Polish providence in western Poland, with overall area of $13,988 \mathrm{~km}^{2}$. The region is mainly flat, with many lakes and woodlands, categorised as a one of the warmest in Poland. The overall temperature is $9.2 \div 7.9^{\circ} \mathrm{C}$ with average annual humidity around $78.8 \div 78.4 \%$ and overall precipitation $585.8 \div 686.1 \mathrm{~mm}$. One of the biggest Voivodeships in Poland is Great Poland Voivodeship, located in west-central Poland. It has an area of $29,826 \mathrm{~km}^{2}$ and agriculture and touristic are two main branches of this region. The Great Poland Voivodeship is influenced by oceanic air masses that affect the mildness of the climate, the overall temperature reaches $9.2 \div 7.7^{\circ} \mathrm{C}$, and the average precipitation varies from $585.5 \mathrm{~mm}$ to $715.3 \mathrm{~mm}$ with humidity about $77.5 \div 79.6 \%$.

\section{Modified Agglutination Test (MAT)}

The sera were tested for the presence of $T$. gondi-specific IgG antibodies using MAT (Toxo-Screen DA, BioMérieux SA, France). Equal volumes $(25 \mu \mathrm{l})$ of the serum sample were added into each well, both the negative and positive controls provided in the kit were included in each test. The dilutions that formed a foil or mesh over at least $50 \%$ of the base of the microplate well were considered as seropositive, and dilutions that formed a compact button or occupied up to $50 \%$ of the base were considered seronegative. A titre of 40 was considered indicative of $T$. gondii infection in the sample (the minimal titre for a positive result in this kit was established as greater or equal to 40 [36].

\section{Statistical Analysis}

The statistical analyses were performed using the StatPages ${ }^{\circledR}$ free statistical software. A chi-square test was used. The differences were statistically significant when $p<0.05$. To calculate the seroprevalence and the $95 \%$ confidence intervals, a binomial confidence intervals calculator was used (https://statpages.info/confint.html).

\section{Results}

Antibodies to T. gondii were detected in $150 / 398$ (37.7\%, 95\% CI $32.9 \%-42.6 \%$ ) wild boar serum samples. The seroprevalence varied between Voivodeships. Among Greater Poland wild boars, the seroprevalence was $11.6 \%$, Lubusz $42 \%$ and Warmian-Masurian 50\%. The statistical analysis showed that there are significant differences between the Great Poland and Lubusz Voivodeships and also between Great Poland and Warmian-Masurian.

Among the positive results, $80.6 \%$ of antibodies were detected in titre range $40-180$, while $16.7 \%$ were found in $540-4000$ and $2.7 \%$ in the $\geq 6000$ range (Table 1 ).

\section{Discussion}

Both livestock and wild boars can act as intermediate host for $T$. gondii. These species may act as one of the sources for parasite transmission to humans [16]. Many epidemiological studies have found an association between the consumption of undercooked or raw meat and T. gondii infection in humans $[5,8,10]$.

T. gondii infection has been reported many times in Poland among farm animals; however, the current status of infection among wildlife is unknown [36, 40]. Earlier studies conducted by Bień et al. [4] revealed 29.8\% seroprevalence among wild boar samples from Lublin Voivodeship and $34.45 \%$ among those from Warmian-Masurian. A similar seroprevalence $(21.1 \%)$ was identified in Lublin Voivodeship by Sroka et al. [36]; however, the number of examined samples was low $(n=52)$. Total $T$. gondii seroprevalence in wild boars reported in the present study (37.7\%) is comparable with that obtained by Witkowski et al. [40] (37.6\%); however, the precise origin of the samples in their study is not stated.

Lower seroprevalences have been detected in bordering countries, with $25 \%$ observed in Germany [27], 8.1\% in Slovakia [2] and 26.2\% in the Czech Republic [3]. Interestingly, a rise in seroprevalence has been observed in Slovakia and the Czech Republic over the following years, reaching 39.7\% and $40 \%$, respectively $[30,31]$.
Table 1 Titre distribution among examined wild boars from three studied Voivodeships

\begin{tabular}{|c|c|c|c|c|c|c|c|c|c|}
\hline \multirow[t]{2}{*}{ Voivodeship } & \multicolumn{9}{|c|}{ Titre } \\
\hline & 40 & 60 & 180 & 540 & 1620 & 4000 & 6000 & 18,000 & Total N/n \\
\hline Great Poland & 2 & 3 & 1 & 0 & 1 & 1 & 0 & 0 & $8 / 69$ \\
\hline Lubusz & 41 & 38 & 17 & 11 & 4 & 4 & 2 & 1 & $118 / 281$ \\
\hline Warmian-Masurian & 8 & 9 & 2 & 2 & 0 & 2 & 1 & 0 & $24 / 48$ \\
\hline Total & 51 & 50 & 20 & 13 & 5 & 7 & 3 & 1 & $150 / 398$ \\
\hline
\end{tabular}

$N$ number of positive samples, $n$ number of examined samples 
Jokelinen et al. [18] used MAT to examine 471 individual wild boar samples submitted by hunters in Estonia, the results showed that 113 (23.99\%) animals had antibodies against $T$. gondii. Seroprevalence presented by Jokelinen et al. is lower comparing to our results, however, it has been proven that the choice of diagnostic method can influence the heterogeneity of results. A higher seroprevalence of $T$. gondii was observed in studies employing ELISA (enzymelinked immunosorbent assay) or MAT than in those which used LAT (latex agglutination test). Using ELISA, the highest prevalence of antibodies to T. gondii in Europe has been demonstrated in wild boars from Sweden $(50 \%)$ and Romania $(56.7 \%)$ [ 15,39$]$. A relatively high prevalence was reported using MAT in studies conducted by Richomme et al. [32] in France (40.4\%) and in Spain (43.5\%) [7]. In contrast, studies performed in China on serum samples using LAT returned a prevalence of $7.2 \%$ (27/377) [26]. Several studies have compared these immunological tests $[13,20$, 33].

Seroprevalence to T. gondii in animals depends not only on serological tests performed but also on several other factors such as presence of felids, climatic conditions, animal species examined. In general, the highest values of seroprevalence of Toxoplasma have been found in game of area with relatively high humidity [14], with an environmental conditions that favour the survival of Toxoplasma oocysts. In our study the highest seroprevalence was observed in Warmian-Masurian Voivodeship with relatively high humidity. The area consist mainly of forests and small villages with many farms. The presence of feral cats and relatively good climate conditions gives opportunity for $T$. gondii oocysts to persist in the environment.

Consumption of raw or undercooked meat of infected animals is the main route of infection in humans in Europe, representing 30-63\% of all infections, depending on the country $[8,10]$. In addition, the EFSA [11] has recommended monitoring game meat for the presence of $T$. gondii. To address these high infection rates, simple post-harvest procedures have been suggested for killing $T$. gondii cysts in meat intended for consumption, such as freezing, heating, irradiation or high-pressure treatment [21]. Interestingly, Kijlstra and Jongert [22] suggest that frozen meat is safe for consumption, with regard to Toxoplasma. They recommend that consumers should freeze the meat for at last 2 days at temperatures below $-12{ }^{\circ} \mathrm{C}$, or properly cook it, to prevent cross-contamination while preparing meat in the kitchen.

Recently, game has become more popular as a meat source for humans in many countries and S. scrofa is the most important game animal species in the world [29]. In addition, wild boar hunting is a popular recreational sport and a population control method supported by wildlife agencies. Despite intensive hunting, the wild boar population of Poland continues to grow. According to data published by the Central Statistical Office of Poland, their number rose from 118300 in 2000 to 264000 in 2015, and the number of hunted wild boar rose threefold during this time. It is important to note that Poland is one of the leading European exporters of game: in 2014, 3363 tonnes of wild boar meat was exported, representing over $30 \%$ of all exported game meat [23]. It was also found that meat products are often produced by combining meat from different animal species, which significantly increases the risk of infection $[1,6]$.

Poland has a strong tradition of consuming wild boar meat. Although the meat is usually heated long enough to inactivate $T$. gondii-infective stages, some specific dishes or products, such as smoked sausage, may not be cooked sufficiently, or at all. Additionally, tasting meat during cooking or poor kitchen hygiene is the main risk factors for human infection. The risk of infection is also exacerbated by the fact that no obligation exists for screening meat for the presence of $T$. gondii during meat inspection.

Wild boar meat is a potential threat not only for humans, but also for other animals. Wild boar infected by $T$. gondii migrates for long distances, and can serve as sources of infection for other scavenging and omnivorous animals through the consumption of infected viscera and carcasses left by hunters [9].

To conclude, our findings indicate a relatively high seroprevalence of $T$. gondii among wild boars originating from three Voivodeships of Poland. Results highlight the zoonotic potential of wild boars, and emphasise that game meat should not be neglected as a significant source of $T$. gondii infection for humans and animals. Both farmed and wild animals living close to human settlements may be exposed to oocysts shed from domestic cats, either directly or via contaminated water. We cannot neglect that poor management and lack of adequate hygiene of hunters handling meat, organs and carcasses of wildlife may play an ecological role in the transmission of $T$. gondii infection. Hunters should rather incinerate carcasses and residuals of hunting to avoid risk of infection to omnivores and carnivores-especially felids that may contaminate environment with oocysts which in turn may infect wild game that will later be consumed by humans. It is recommended that surveillance programmes should be implemented in Europe.

Acknowledgements We thank Lesław Szabłoński, Anna Bronicka and Mieczysława Krygier from the Voivodeship Inspectorate of Veterinary in Poznań and Grzegorz Górecki from the Department of Game Management and Forest Protection, Faculty of Forestry, Poznań University of Life Sciences, for their help in collecting samples.

Author Contributions ACM designed the experiment. Sample preparation: PN and WJ. Laboratory assays: AC and AW. Data interpretation: AK. Drafting the manuscript and revising it critically for important intellectual content: AK, BM and ACM. Final approval of the version to be published: AK and BM. All authors read and approved the final manuscript. 
Funding This study was supported by Poznan University of Medical Sciences, Faculty of Medicine I, Poznan, Poland (Grant no. 502-1-0003496).

Data Availability Data supporting the conclusions of this article are included within the article.

\section{Compliance with Ethical Standards}

Conflict of interest The authors declare that they have no competing interests.

Ethics Approval Not applicable.

Consent for Publication Not applicable.

Open Access This article is licensed under a Creative Commons Attribution 4.0 International License, which permits use, sharing, adaptation, distribution and reproduction in any medium or format, as long as you give appropriate credit to the original author(s) and the source, provide a link to the Creative Commons licence, and indicate if changes were made. The images or other third party material in this article are included in the article's Creative Commons licence, unless indicated otherwise in a credit line to the material. If material is not included in the article's Creative Commons licence and your intended use is not permitted by statutory regulation or exceeds the permitted use, you will need to obtain permission directly from the copyright holder. To view a copy of this licence, visit http://creativecommons.org/licenses/by/4.0/.

\section{References}

1. Akkoc N, Kuruuzum Z, Akar S, Yuce A, Onen F, Yapar N, Ozgenc O, Turk M, Ozdemir D, Avci M, Guruz Y, Oral AM, Pozio E (2009) Izmir Trichinellosis Outbreak Study Group. A large-scale outbreak of trichinellosis caused by Trichinella britovi in Turkey. Zoonoses Public Health 56:65-70

2. Antolová D, Reiterová K, Dubinský P (2007) Seroprevalence of Toxoplasma gondii in wild boars (Sus scrofa) in the Slovak Republic. Ann Agric Environ Med 14:71-73

3. Bártová E, Sedlák K, Literák I (2006) Prevalence of Toxoplasma gondii and Neospora caninum antibodies in wild boars in the Czech Republic. Vet Parasitol 142:150-153

4. Bień J, Moskwa B, Pastusiak K, Cabaj W (2005) Seroprevalence of Toxoplasma gondii in domestic pigs and wild boars from different district of Poland. Wiad Parazytol 51(Suppl 1):52-53

5. Boyer KM, Holfels E, Roizen N, Swisher C, Mack D, Remington J, Withers S, Meier P, McLeod R (2005) Risk factors for Toxoplasma gondii infection in mothers of infants with congenital toxoplasmosis: Implications for prenatal management and screening. Am J Obstet Gynecol 192:564-571

6. Cai Y, He Y, Lv R, Chen H, Wang Q, Pan L (2017) Detection and quantification of beef and pork materials in meat products by duplex droplet digital PCR. PLoS One 12(8):e0181949

7. Closa-Sebastià F, Casas-Díaz E, Cuenca R, Lavín S, Mentaberre G, Marco I (2011) Antibodies to selected pathogens in wild boar (Sus scrofa) from Catalonia (NE Spain). Eur J Wildlife Res 57:977-981

8. Cook AJ, Gilbert RE, Buffolano W, Zufferey J, Petersen E, Jenum PA, Foulon W, Semprini AE, Dunn DT (2000) Sources of Toxoplasma infection in pregnant women: European multicentre casecontrol study. BMJ 321:142-147
9. De Graaf RM, Yamasaki M (2001) New England wildlife: habitat, natural history and distribution. University Press of New England, Hanover

10. Dubey JP (2010) Toxoplasmosis of animals and humans, 2nd edn. Boca Raton, Florida, CRC Press

11. EFSA, European Food Safety Authority (2007) Surveillance and monitoring of Toxoplasma in humans, food and animals Scientific Opinion of the Panel on Biological Hazards. EFSA J 583:1-64

12. FAO/WHO [Food and Agriculture Organization of the United Nations/World Health Organization] (2014) Multicriteria-based ranking for risk management of food-borne parasites. MRA 23. Rome. 302

13. Gamble HR, Dubey J, Lambillotte DN (2005) Comparison of a commercial ELISA with the modified agglutination test for detection of Toxoplasma infection in the domestic pig. Vet Parasitol 128:177-181

14. Gauss CB, Dubey JP, Vidal D, Cabezón O, Ruiz-Fons F, Vicente J, Marco I, Lavin S, Gortazar C, Almería S (2006) Prevalence of Toxoplasma gondii antibodies in red deer (Cervus elaphus) and other wild ruminants from Spain. Vet Parasitol 136:193-200

15. Grema C, Hotea I, Imre M, Dărăbuș G, Pascu C, Mariș C, Herman V (2015) Seroprevalence of Toxoplasmosis and swine influenza in wild boars. Sci Parasitol 16:20-27

16. Guo M, Dubey JP, Hill D, Buchanan RL, Gamble HR, Jones JL, Pradhan AK (2015) Prevalence and risk factors for Toxoplasma gondii infection in meat animals and meat products destined for human consumption. J Food Prot 78:457-476

17. Hill DE, Dubey JP (2016) Toxoplasma gondii as a parasite in food: analysis and control. Microbiol Spectrum 4:PFS-00112015. doi: 10.1128/microbiolspec.PFS-0011-2015

18. Jokelainen P, Velström K, Lassen B (2015) Seroprevalence of Toxoplasma gondii in free-ranging wild boars hunted for human consumption in Estonia. Acta Vet Scand 57:42

19. Jones JL, Dubey JP (2012) Foodborne toxoplasmosis. Clin Infect Dis 55:845-851

20. Kornacka A, Cybulska A, Bień J, Goździk K, Moskwa B (2016) The usefulness of direct agglutination test, enzyme-linked immunosorbent assay and polymerase chain reaction for the detection of Toxoplasma gondii in wild animals. Vet Parasitol 228:85-89

21. Kijlstra A, Jongert E (2008) Control of the risk of human toxoplasmosis transmitted by meat. Int J Parasitol 38:1359-1370

22. Kijlstra A, Jongert E (2008) Toxoplasma-safe meat: close to reality? Trends Parasitol 25:18-22

23. Kilar J, Ruda M, Kilar M (2016) Dziczyzna. Co o niej wiedzą i czy ją jedzą mieszkańcy Podkarpacia.Państwowa Wyższa Szkoła Zawodowa im. Stanisława Pigonia w Krośnie. Krosno, pp 100

24. Laddomada A (2000) Incidence and control of CSF in wild boar in Europe. Vet Microbiol 73:121-130

25. Lowe S, Browne M, Boudjelas S, De Poorter M (2000) 100 of the World's worst invasive Alien species. A selection from the Global Invasive Species Database. Published by The Invasive Species Specialist Group (ISSG) a specialist group of the Species Survival Commission (SSC) of the World Conservation Union (IUCN), $12 \mathrm{pp}$. First published as special lift-out in Aliens 12, December 2000. Updated and reprinted version: November 2004.

26. Luo H, Li K, Shahzad M, Zhang H, Lan Y, Xiong X (2017) Seroprevalence of Toxoplasma gondii infection in wild boars, wild rabbits, and wild chickens in Hubei province, China. Kor J Parasitol 55:85-88

27. Lutz W (1997) Serologischer Nachweis von Antikörpern gegen Toxoplasma gondii und Leptospira bei Schwarzwild. Z Jagdwiss 43:283-287 
28. Meng XJ, Lindsay DS, Sriranganathan N (2009) Wild boars as sources for infectious diseases in livestock and humans. Philos Trans R Soc Lond B Biol Sci 364:2697-2707

29. Massei G, Kindberg J, Licoppe A, Gačić D, Šprem N, Kamler J, Baubet E, Hohmann U, Monaco A, Ozoliņ̌ J (2015) Wild boars populations up, numbers of hunters down? A review of trends and implications for Europe. Pest Manag Sci 71:492-500

30. Račka K, Bártová E, Budíková M, Vodrážka P (2015) Survey of Toxoplasma gondii antibodies in meat juice of wild boar (Sus scrofa) in several districts of Czech Republic. Ann Agric Environ Med 22:231-235

31. Reiterová K, Špilovská S, Blaňarová L, Derdáková M, Čobádiová A, Hisira V (2016) Wild boar (Sus scrofa)-reservoir host of Toxoplasma gondii, Neospora caninum and Anaplasma phagocytophilum in Slovakia. Acta Parasitol 61:255-260

32. Richomme C, Afonso E, Tolon V, Ducrot C, Halos L, Alliot A, Perret C, Thomas M, Boireau P, Gilot-Fromont E (2010) Seroprevalence and factors associated with Toxoplasma gondii infection in wild boar (Sus scrofa) in a Mediterranean island. Epidemiol Infect 138:1257-1266

33. Rostami A, Riahi SM, Fakhri Y, Saber V, Hanifehpour H, Valizadeh S, Gholizadeh M, Pouya RH, Gamble HR (2017) The global seroprevalence of Toxoplasma gondii among wild boars: a systematic review and meta-analysis. Vet Parasitol 244:12-20
34. Slany M, Reslova N, Babak V, Lorencova A (2016) Molecular characterization of Toxoplasma gondii in pork meat from different production systems in the Czech Republic. Int J Food Microbiol 238:252-255

35. Slifko TR, Smith HV, Rose JB (2000) Emerging parasite zoonoses associated with water and food. Int J Parasitol 30:1379-1393

36. Sroka J, Zwoliński J, Dutkiewicz J (2007) Seroprevalence of Toxoplasma gondii in farm and wild animals. Bull Vet Inst Pulawy 51:535-540

37. Tenter AM, Heckeroth AR, Weiss LM (2000) Toxoplasma gondii: from animals to humans. Int J Parasitol 30:1217-1258

38. Torgerson PR, de Silva NR, Fèvre EM, Kasuga F, Rokni MB, Zhou XN, Sripa B, Gargouri N, Willingham AL, Stein C (2014) The global burden of foodborne parasitic diseases: an update. Trends Parasitol 230:20-26

39. Wallander C, Frössling J, Vagsholm I, Uggla A, Lunden A (2015) Toxoplasma gondii seroprevalence in wild boars (Sus scrofa) in Sweden and evaluation of ELISA test performance. Epidemiol Infect 143:1913-1921

40. Witkowski L, Czopowicz M, Nagy DA, Potarniche AV, Aoanei MA, Imomov N, Mickiewicz M, Welz M, Szalus-Jordanow O, Kaba J (2015) Seroprevalence of Toxoplasma gondii in wild boars, red deer and roe deer in Poland. Parasite 22:17 